\title{
Pengaruh Level Penggunaan Jamur Mikoriza terhadap Komposisi Nutrisi Hijauan Sorgum Sebagai Pakan
}

\author{
(The Effect Of Vesicular-Arbuscular \\ Mycorrhizal Level on The Nutrient \\ Composition Of Sorghum Forage As Feed)
}

\author{
Alfonsius Minu Mali ${ }^{\# 1}$, Bernadete B. Koten ${ }^{1}$, Devi A. J. Ndolu ${ }^{2}$, Helda ${ }^{2}$, Jacobus S. OEmatan ${ }^{2}$, \\ Redempta Wea ${ }^{2}$ \\ ${ }^{1}$ Program Studi Teknologi Pakan Ternak, ${ }^{2}$ Program Studi Produksi Ternak \\ Jurusan Peternakan Politeknik Pertanian Negeri Kupang \\ Jl. Prof. Dr. Herman Yohanes Lasiana Kupang, P.O Box. 1152, Kupang 85011 \\ \#Email: alfonsiusmallyegmail.com
}

\begin{abstract}
The study aimed to evaluate the nutrient composition of sorghum forage with the addition of vesicular-arbuscular mycorrhizal fungi (VAM) was conducted for 5 months from June to November 2016. Sorghum is grown in polybags and placed on the forage land of the State Agricultural Polytechnic of Kupang. This study was conducted using a completely randomized design with 4 treatments and 5 replications, The treatment were: without mycorrhizal fungi (S0), mycorrhizal fungi 5 gram/polybag (S5), mycorrhizal fungus $10 \mathrm{gram} / \mathrm{polybag}$ (S10) and mycorrhizal fungus $15 \mathrm{gram} /$ polybag. The measured variables were dry matter (DM) content, ash content, crude protein (CP) content, ether extract (EE) content, crude fiber (CF) content and nitrogen free ekstract (NFE) content. The data were analyzed by analysis of variance and followed by Duncan's multiple-range test. The results showed that the level of mycorrhizal fungi use only significant $(P<0.05)$ to the ether extract $(\mathbf{E E})$ content, crude fiber (CF) content and nitrogen free ekstract (NFE) content, while the content of dry matter (DM), ash content and crude protein $(\mathrm{CP})$ content No significant effect $(\mathrm{P}>\mathbf{0 . 0 5})$. The Average dry matter content $16,27 \%$; ash content of $11.03 \%$; crude protein content of $10.12 \%$; ether extract content $2.94 \%$; crude fiber content $22.61 \%$ and NFE content $53.30 \%$.
\end{abstract}

Keywords : sorghum forage, vesicular-arbuscular mycorrhizal (VAM) level, nutrient composition.

\section{Pendahuluan}

Ternak ruminansia akan berproduksi dengan baik apabila ketersediaan pakan hijauan yang bermutu mencukupi dan berkesinambungan. Kondisi ini masih merupakan kendala di Nusa Tenggara Timur (NTT) terutama pada musim kemarau, sehingga perlu dibudidayakan tanaman pakan yang tahan terhadap kekeringan seperti sorgum. Sorgum (Sorghum bicolor (L.) Moench) merupakan tanaman serealia yang mempunyai daya adaptasi tinggi yakni lebih tahan terhadap kekeringan jika dibandingkan dengan tanaman serealia yang lainnya serta dapat tumbuh hampir di setiap jenis tanah. Koten et al. (2014) melaporkan bahwa hijauan sorgum dapat dimanfaatkan sebagai pakan ternak ruminansia (kambing) dengan tingkat konsumsi 19,53 g/kg bobot badan BK; 19,75 g/kg bobot badan BO; $1,33 \mathrm{~g} / \mathrm{kg}$ bobot badan PK; 7,48 $\mathrm{g} / \mathrm{kg}$ bobot badan SK; $0,52 \mathrm{~g} / \mathrm{kg}$ bobot badan EE; $10,78 \mathrm{~g} / \mathrm{kg}$ bobot badan BETN; $1,45 \mathrm{~g} / \mathrm{kg}$ bobot badan abu. Dengan demikian tanaman ini berpotensi untuk dibudidayakan sebagai sumber pakan hijauan pada lahan kering dan marjinal seperti NTT. Untuk menunjang pertumbuhan tanaman sorgum di daerah marjinal sehingga dapat berproduksi dengan maksimal maka perlu penambahan agen hayati yaitu Mikoriza vesikular-arbuskular (MVA).

Mikoriza ini berpotensi sebagai salah satu alternatif teknologi untuk meningkatkan pertumbuhan dan produktivitas tanaman terutama pada lahan-lahan marginal yang kurang subur. Mikoriza vesikular-arbuskular (MVA) merupakan suatu struktur yang ddibentuk oleh asosiasi simbiotik mutualisme antara cendawan tanah dan 
Alfonsius Minu Mali, Bernadete B. Koten, Devi A. J. Ndolu, Helda, Jacobus S. OEmatan, Redempta

Wea. Pengaruh Level Penggunaan Jamur Mikoriza terhadap Komposisi Nutrisi Hijauan Sorgum sebagai

Pakan

sel akar tumbuhan (tanaman inang). Dalam asosiasi simbiosis mutualis tersebut, tanaman inang menerima nutrisi unsur hara mineral sedangkan cendawan mikoriza mendapat suplai karbon sebagai derivat fotosintesis dari tanaman inang, dilanjutkan bahwa pemberian mikoriza mampu meningkatkan kemampuan tanaman dalam beradaptasi terhadap lingkungan, baik dalam bentuk penyerapan air maupun unsur hara karena mikoriza mampu meningkatkan kapasitas penyerapan unsur hara serta berfungsi untuk meningkatkan produktivitas tanaman (Lukiwati, 2013). Di daerah lahan kering seperti NTT, mikoriza arbuskula sebanyak 15 gram perpolibag (perumpun tanaman) dapat bersimbosa dengan tanaman sorgum yang mampu meningkatkan pertumbuhan, produksi hijauan dan kadar phosphor hijauan sorgum (Mbeong, 2016). Level mikoriza yang diinokulasikan menentukan jumlah mikoriza yang akan aktif di sekitar media tanam. Banyaknya mikoriza ini akan mempengaruhi proses fotosintesis dan produktivitas sorgum sebagai pakan. Level mikoriza inipun akan berdampak juga terhadap komposisi nutrisi hijauan sorgum.

Berdasarkan pemikiran tersbut maka telah dilaksanakan suatu penelitian dengan judul "Pengaruh Level Penggunaan Jamur Mikoriza Terhadap Komposisi Nutrisi Hijauan Sorgum Sebagai Pakan”. Tujuan dari penelitian ini adalah untuk mengkaji pengaruh level penggunaan jamur mikoriza terhadap komposisi nutrisi hijauan sorgum.

\section{METODE PENELITIAN \\ Waktu dan Lokasi}

Penelitian ini telah dilaksanakan selama 5 bulan dari bulan Juni hingga November 2016. Sorgum ditanam dalam polibag dan diletakan di lahan hijauan makanan ternak Politeknik Pertanian Negeri Kupang.

\section{Bahan dan Alat Penelitian}

Bahan yang digunakan adalah benih sorgum, mikoriza, pupuk dasar (feses sapi kering), pupuk NPK, tanah dan air bersih .

Peralatan yang digunakan adalah linggis utuk membongkar tanah, pengayak tanah digunakan untuk mengayak tanah, polibag dengan ukuran $38 \mathrm{~cm} \times 20 \mathrm{~cm} \times 20 \mathrm{~cm}$ sebagai media tanam, timbangan digital (merek Defender 3000 kapasitas $150 \mathrm{~kg}$ skala terkecil $1 \mathrm{~kg}$ ) digunakan untuk menimbang tanah dan pupuk dasar (feses sapi kering), timbangan digital (merek Camry kapasitas 5 $\mathrm{kg}$ skala terkecil 1 gram) digunakan untuk menimbang mikoriza dan pupuk NPK, jaring sebagai sekat pelindung bagi materi penelitian, thermometer untuk mengukur suhu lingkungan dan perangkat peralatan laboratorium untuk melakukan analisis proksimat.

\section{Prosedur Penelitian}

Persiapan tanah meliputi pembongkaran dan penghancuran tanah, kemudian dimasukkan ke dalam polibag sebanyak $10 \mathrm{~kg} /$ polibag. Polibag ditempatkan dengan jarak 0,6×0,4 meter. Penentuan perlakuan pada polibag dilakukan secara acak berdasarkan pola RAL. Benih sorgum dipilih dari biji yang memenuhi syarat bibit yang baik. Penanaman dilakukan dengan membuat lubang tanam dalam polibag. Dalam 1 polibag ditanam 5 biji sorgum, kemudian ditutup kembali.

Penjarangan tanaman dilakukan pada hari ke-14 dengan hanya meninggalkan 2 tanaman terbaik/polibag, selanjutnya dilakukan pemupukan menggunakan pupuk NPK dengan dosis 2,4 gram/polibag. Penyiraman tanaman dilakukan setiap hari hingga pemanenan.

Pada saat panen dilakukan pengukuran terhadap produksi hijauannya. Pemotongan tanaman telah dilakukan pada batang dengan jarak $\pm 5 \mathrm{~cm}$ dari atas tanah. Hijauan yang diperoleh dimasukkan dalam kantong koran yang telah diketahui beratnya kemudian dikeringkan dalam oven dengan suhu $60^{\circ} \mathrm{C}$ selama 3 hari hingga mencapai berat konstan. Sampel hijauan tersebut digiling halus dan selanjutnya dilakukan analisis proksimat (AOAC, 2005).

\section{Variabel yang Diamati}

Variabel yang diamati adalah komposisi nutrisi hijauan sorgum berupa kadar bahan kering (BK), kadar protein kasar (PK), kadar serat kasar (SK), kadar lemak kasar (LK), kadar bahan ekstrak tanpa nitrogen (BETN) dan kadar abu (AOAC, 2005).

Rancangan Percobaan yang Digunakan

Penelitian ini dirancang dengan menggunakan rancangan acak lengkap (RAL) dengan 4 perlakuan dan 5 ulangan, perlakuan yang di cobakan meliputi:

S0 = Tanpa jamur mikoriza (kontrol)

S5 = level jamur mikoriza 5 gram/polibag

$\mathrm{S} 10=$ level jamur mikoriza 10 gram/polibag

$\mathrm{S} 15$ = level jamur mikoriza 15 gram/polibag

\section{Analisis Data}

Hasil penelitian dianalisis dengan menggunakan statistika Analisis Varian (Anava), jika terdapat perbedaan yang nyata dilanjutkan dengan uji jarak berganda Duncan dengan tingkat $5 \%$ untuk menentukan perlakuan mana yang berbeda dengan perlakuan lain (Gomez dan Gomez, 2010).

\section{HASIL DAN PEMBAHASAN}

\section{Kadar Bahan Kering Hijauan Sorgum Akibat Perlakuan}

Tabel rerata kadar BK tanaman sorgum dengan perlakuan level penggunaan jamur mikoriza 
yang berbeda belum berpengaruh terhadap kadar bahan kering hijauan sorgum. Rata-rata tertinggi terdapat pada perlakuan S15 yaitu $16,85 \%$ yang diiuti perlakuan S0 yaitu $16,18 \%$, S5 yaitu $16,14 \%$ dan rata-rata terendah terdapat pada perlakuan $\mathrm{S} 10$ yaitu $15,92 \%$.

TABEL 1. RERATA KOMPOSISI NUTRISI HIJAUAN SORGUM AKIBAT PERLAKUAN (\%)

\begin{tabular}{|c|c|c|c|c|c|c|}
\hline \multirow{2}{*}{$\begin{array}{l}\text { Perlak } \\
\text { uan }\end{array}$} & \multicolumn{6}{|c|}{ Variabel } \\
\hline & BK & PK & SK & LK & $\begin{array}{l}\text { BET } \\
\mathrm{N}\end{array}$ & $\begin{array}{l}\mathrm{AB} \\
\mathrm{U}\end{array}$ \\
\hline S0 & $\begin{array}{l}16.1 \\
8^{\text {tn }}\end{array}$ & $\begin{array}{l}9.90 \\
\text { tn }\end{array}$ & $\begin{array}{l}20.3 \\
2^{\mathrm{b}}\end{array}$ & $\begin{array}{l}2.70 \\
4^{\mathrm{b}}\end{array}$ & $\begin{array}{l}55.6 \\
3^{\mathrm{a}}\end{array}$ & $\begin{array}{l}11.4 \\
5^{\text {th }}\end{array}$ \\
\hline S5 & $\begin{array}{l}16.1 \\
4^{\text {tn }}\end{array}$ & $\begin{array}{l}10.7 \\
8^{\operatorname{tn}}\end{array}$ & $\begin{array}{l}22.5 \\
5^{a}\end{array}$ & $\begin{array}{l}3.14 \\
6^{\mathrm{a}}\end{array}$ & $\begin{array}{l}53.3 \\
4^{\mathrm{a}}\end{array}$ & $\begin{array}{l}10.1 \\
8^{\operatorname{tn}}\end{array}$ \\
\hline $\mathrm{S} 10$ & $\begin{array}{l}15.9 \\
2^{\text {tn }}\end{array}$ & $\begin{array}{l}10.5 \\
5^{\text {tn }}\end{array}$ & $\begin{array}{l}25.0 \\
6^{a}\end{array}$ & $\begin{array}{l}3.15 \\
2^{\mathrm{a}}\end{array}$ & $\begin{array}{l}49.8 \\
6^{\mathrm{b}}\end{array}$ & $\begin{array}{l}11.3 \\
9^{\operatorname{tn}}\end{array}$ \\
\hline S15 & $\begin{array}{l}16.8 \\
5^{\text {tn }}\end{array}$ & $\begin{array}{l}9.25 \\
\mathrm{tn}\end{array}$ & $\begin{array}{l}22.5 \\
1^{\mathrm{a}}\end{array}$ & $\begin{array}{l}2.74 \\
0^{\mathrm{b}}\end{array}$ & $\begin{array}{l}54.3 \\
9^{\mathrm{a}}\end{array}$ & $\begin{array}{l}11.1 \\
1^{\mathrm{tn}}\end{array}$ \\
\hline
\end{tabular}

level penggunaan jamur mikoriza tidak berpengaruh nyata $(\mathrm{P}>0,05)$ terhadap kadar bahan kering hijauan sorgum. Kondisi ini dipengaruhi oleh waktu yang dimanfaatkan untuk berfotosintesis oleh tanaman sorgum sama karena dipanen serentak sehingga banyaknya akumulasi hasil fotosintesis di dalam jaringan tanaman tidak berbeda pula. Hal ini sesuai dengan pendapat Gardner et al. (2008) yang melaporkan bahwa semakin lama terjadinya asimilasi makin tinggi bahan kering tanaman, dilanjutkan lagi bahwa proses fotosintesis sangat dipengaruhi oleh daya kerja peralatan fotosintesis termasuk klorofil. Selanjutnya Koten et al. $\left(2012^{\mathrm{b}}\right)$ berpendapat bahwa klorofil mengandung $\mathrm{N}$, dengan demikian makin banyak $\mathrm{N}$ yang tersedia makin tinggi hasil fotosintesisnya.

Rerata kadar bahan kering hijauan Sorgum pada penelitian ini adalah $16,27 \%$ lebih rendah dibandingkan dengan hasil penelitian Yoku (2010) yaitu 22,68\% pada perlakuan Produksi Hijauan dan Nilai Nutrisi Wafer Rumput Sudan (Sorgum Sudaneses) Sebagai Bahan Pakan Ternak Ruminansia.

\section{Kadar Protein Kasar Hijauan Sorgum Akibat Perlakuan}

Hasil penelitian memperlihatkan bahwa kadar protein tertinggi terdapat pada perlakuan S5 yaitu $10,78 \%$ yang diikuti dengan perlakuan $\mathrm{S} 10$ yaitu $10,55 \%$, S0 yaitu $9,90 \%$ dan S15 yaitu $9,25 \%$. Dari hasil yang ada terdapat perbedaan antara perlakuan namun perbedaannya tidak signifikan melalui hasil uji analisis varians. Perbedaan tidak signifikan ini disebabkan oleh persediaan unsur hara nitrogen yang tersedia pada media tanam (tanah) dalam jumlah dan volume yang sama yaitu $0.25 \% \mathrm{~N}$ total dalam $10 \mathrm{~kg}$ tanah/polibag serta kemampuan jamur mikoriza vesicular-arbuskular yang bersimbisis dengan akar tanaman untuk menyerap nitrogen.

Kebutuhan tanaman pakan akan nitrogen $(\mathrm{N})$ sangat tinggi terutama dari kelompok rumput-rumputan termasuk sorgum. Nitrogen ini berguna untuk meningkatkan pertumbuhan, produksi dan kualitas hijauan tanaman. Kondisi ini menyebabkan akumulasi hasil fotosintesis dalam tanaman dapat berlangsung lebih lama sehingga meningkatkan produktivitas tanaman sebagai pakan (Koten, et al. 2012 ), diperkuat oleh Gardner et al. (2008) menjelaskan bahwa nitrogen merupakan bahan penyusun asam amino, amida, basa bernitrogen seperti purin, dan protein serta nukleoprotein.

Rerata kadar protein kasar hijauan Sorgum pada penelitian ini adalah $10,12 \%$ dengan umur panen 52 hari, hasil ini terlihat lebih rendah dibandingkan penelitian Koten et al. $\left(2012^{\mathrm{a}}\right)$ yang melaporkan bahwa rerata $\mathrm{PK}$ sorgum pada umur 50 hari adalah 11,52\%.

\section{Kadar Serat Kasar Hijauan Sorgum Akibat Perlakuan}

Berdasarkan hasil analisis varians memperlihatkan bahwa level penggunaan jamur mikoriza memberikan pengaruh yang nyata $(\mathrm{P}<0,05)$ terhadap kadar serat kasar hijauan sorgum. Hasil uji Duncan menunjukkan bahwa kadar serat kasar yang tertinggi terdapat pada perlakuan S10 yaitu $25,06 \%$ yang berbeda dengan S0, S5 dan S15. Antara S10, S5 dan S15 tidak terdapat perbedaan yang nyata $(\mathrm{P}>0,05)$, namun pada perlakuan $\mathrm{S} 0$ dan $\mathrm{S} 10$ terdapat perbedaan yang nyata $(\mathrm{P}<0,05)$. Perbedaan yang nyata ini disebabkan level pemberian mikoriza yang mampu membantu akar tanaman sorgum dalam penyerapan senyawa organik terutama karbohidrat yang mengandung hemiselulosa dan selulosa serta lignin.

Sutanto (2005) menyatakan sisa tanaman dan hewan mengalami proses peruraian/dekomposisi oleh mikroorganisme dan diurai menjadi molekul dan ion atau mengalami proses alihrupa menjadi humus oleh proses humifikasi. Karbohidrat dan lignin diuraikan menjadi senyawa anorganik yang lebih sederhana seperti $\mathrm{NH}_{4}, \mathrm{NO}_{3}, \mathrm{P}, \mathrm{S}, \mathrm{Ca}, \mathrm{K}, \mathrm{Mg}$ dan Fe serta senyawa humin. Pada humus tanah terdapat 40$45 \%$ kandungan lignin. Unsur-unsur hara dalam tanah tersedia dalam bentuk senyawa yang ada di dalam larutan tanah berupa ion bebas yang akan diabsorbsi oleh akar tanaman dengan bantuan jamur mikoriza untuk membentuk jaringan pada tanaman semasa tanaman hidup.

Tinggi rendahnya produksi kadar serat kasar hijauan sorgum dapat dipengaruhi pula oleh umur tanaman dan produksi biomasa hijauan 
sorgum, diketahui rata-rata produksi biomasa hijauan sorgum dari penelitian ini yakni $\mathrm{S} 0=$ 763,06 gram, $\mathrm{S} 5=1017,18$ gram, $\mathrm{S} 10=798,12$ gram dan $\mathrm{S} 15=793,64$ gram, dengan rata-rata tertinggi terdapat pada perlakuan S5 dan S10. Nugroho et al. (2010) melaporkan bahwa semakin dewasa tanaman maka akan semakin mengalami penebalan dinding selnya. Protoplas akan mengekspresikan dinding sel sekunder setelah sel berhenti membesar.

Rerata kadar serat kasar hijauan Sorgum pada penelitian ini adalah $22,61 \%$ lebih rendah dibandingkan dengan hasil penelitian Koten et al. $\left(2012^{\mathrm{a}}\right)$ yaitu sebesar $30,41 \%$ dengan perlakuan umur panen yang berbeda dan dosis pupuk urea pada sorgum. Rerata kadar serat kasar dalam penelitian ini hampir mencapai kisaran kadar serat kasar rumput sudan (Sorghum sudanense) yang berkisar antara 23,3231,28\% (Yoku, 2010).

\section{Kadar Lemak Kasar Hijauan Sorgum Akibat Perlakuan}

Berdasarkan hasil analisis varians memperlihatkan bahwa level penggunaan jamur mikoriza ternyata berpengaruh nyata $(\mathrm{P}<0,05)$ terhadap kadar lemak kasar hijauan sorgum. Hasil uji Duncan memperlihatkan bahwa kadar lemak kasar tertinggi terdapat pada perlakuan S10 yaitu $3,152 \%$ yang berbeda nyata $(\mathrm{P}<0,05)$ dengan perlakuan S0 dan S15, antara perlakuan S10 dan S5 tidak berpengaruh nyata. Perbedaan yang nyata disebabkan karena kemampuan akar sorgum yang bersimbiosis dengan jamur mikoriza sesuai level pemberian untuk menyerap unsur-unsur hara dalam bentuk senyawa organik, senyawa mineral, unsur yang terjerap dan unsur dalam larutan tanah yang berupa ion bebas. Senyawa-senyawa ini diserap oleh akar tanaman sorgum dari dalam tanah untuk membentuk kandungan lemak kasar pada jaringan tanaman hijauan sorgum.

Sutanto (2005) menyatakan Terbentuknya senyawa-senyawa ini dari proses alihrupa bahan organik melalui proses mineralisasi bahan organik yang meliputi proses peruraian/dekomposisi dan proses humifikasi. Kandungan lemak kasar juga terbentuk dari senyawa humin hasil alihrupa dari proses humifikasi dan dari humus yang masih terdapat kandungan lemak dan lilin.

Zat lilin dan asam lemak dari hijauan sorgum terutama pada lapisan permukaan daun memiliki kandungan lemak kasar yang cukup besar karena adanya lapisan lilin yang berfungsi untuk mengurangi penguapan air dan sebagai lapisan pelindung pada bagian permukaan daun sehingga tanaman sorgum dapat bertahan hidup di daerah panas dan cekaman kekeringan serta tahan terhadap hama dan penyakit. Oleh karena itu, produksi hijuauan sorgum terutama daun dapat mempengaruhi kandungan lemak kasar hijauan sorgum, diketahui rata-rata produksi daun sorgum dari penelitian ini yaitu $\mathrm{S} 0=352,96$ gram, S5= 472,38 gram, $\mathrm{S} 10=393,42$ gram dan $\mathrm{S} 15=385,22$ gram, dengan rata-rata tertinggi terdapat pada perlakuan S5 dan S10.

Rerata kadar lemak kasar hijauan sorgum pada penelitian ini adalah 2,94\% lebih rendah dibanding penelitian Koten et al. $\left(2012^{\mathrm{a}}\right)$ yaitu sebesar 5,16\% dengan perlakuan umur panen yang berbeda dan dosis pupuk urea pada sorgum. Namun rerata kadar lemak kasar dari penelitian ini lebih tinggi jika dibandingkan penelitian Sirappa (2003) yakni sebesar 2,60\% pada hijauan Sorghum bicolor

\section{Kadar BETN Hijauan Sorgum Akibat Perlakuan}

Hasil analisis varians menunjukkan bahwa level penggunaan jamur mikoriza ternyata memberikan berpengaruh yang nyata $(\mathrm{P}<0,05)$ terhadap kadar BETN hijauan sorgum. Hasil uji Duncan memperlihatkan bahwa kadar BETN yang tertinggi terdapat pada perlakuan S0 yaitu 55,63\% yang berbeda dengan S5, S10 dan S15. Antara S0, S5 dan S15 tidak terdapat perbedaan yang nyata (P>0,05), namun pada S0 dan S10 terdapat perbedaan yang nyata $(\mathrm{P}<0,05)$. Perbedaan yang nyata disebabkan oleh hasil perhitungan komponen lainnya seperti kadar abu, serat kasar, protein kasar dan lemak kasar yang dapat mempengaruhi kadar BETN. Hal ini sesuai dengan Soejono (1991) menyatakan bahwa kandungan BETN suatu bahan pakan sangat tergantung pada komponen lainnya, seperti abu, protein kasar, serat kasar dan lemak kasar. Hal ini disebabkan penentuan kandungan BETN hanya berdasarkan perhitungan dari zat-zat yang tersedia. Bias yang ditentukan pada perhitungan tergatung pada keragaman hasil yang diperoleh.

Rerata kadar BETN hijauan sorgum pada penelitian ini adalah 53,30\%. Rerata ini lebih tinggi dibanding rerata kadar BETN tanaman Sorgum bicolor seperti yang dilaporkan oleh Koten et al. (2012a) yaitu $48,56 \%$, namun berada dalam kisaran kadar BETN tanaman rumput sudan yaitu 44,80-55,38\% yang dilaporkan oleh (Yoku, 2010).

\section{Kadar Abu Hijauan Sorgum Akibat Perlakuan}

Hasil analisis varians memperlihatkan bahwa pemberian level mikoriza yang berbeda tidak memberikan pengaruh yang nyata $(\mathrm{P}>0,05)$ terhadap kadar abu hijauan sorgum. Hasil rata-rata tiap perlakuan terlihat bahwa kadar abu tertinggi terdapat pada perlakuan S0 yaitu 11,45\% disusul oleh perlakuan S10 yaitu 11,39\%, S15 yaitu $11,11 \%$ dan S5 yaitu $10,18 \%$. Kondisi ini dipengaruhi oleh ketersediaan bahan organik dalam tanah yang dibutuhkan oleh tanaman sorgum dalam jumlah yang sama sehingga berdampak pula pada 
kandungan bahan anorganik dalam jaringan tanaman sorgum, namun seiring bertambahnya umur tanaman semakin berkurang pula kadar bahan anorganiknya. Hal ini sesuai Koten (2013) melaporkan bahwa pada umur panen yang tinngi maka semakin banyak mineral yang dimanfaatkan oleh tanaman dalam menunjang proses pertumbuhan dan produksi tanaman. Kondisi ini menyebabkan semakin berkurangnya kadar bahan anorganik pada jaringan tanaman.

Umur panen sorgum dari penelitian ini pada hari ke-52 sebelum tanaman sorgum memasuki masa generatif. Oleh karena itu, jumlah kandungan mineral yang diserap oleh tanaman sorgum dengan bantuan jamur mikoroisa terutama unsur $\mathrm{P}$ semakin banyak, yang dimana mikoriza membantu merombak asam fitat dalam bahan organik tanah sehingga unsure hara $\mathrm{P}$ dapat tersedia bagi tanaman sorgum. Balabanli et al. (2010) menjelaskan bahwa meningkatnya kadar bahan organik menyebabkan semakin berkurangnya kadar bahan anorganik pada jaringan tanaman, pada umur panen yang tinggi maka semakin meningkat kadar bahan organik yang merupakan akumulasi hasil fotosintesa. Nurbaity (2000) melaporkan bahwa mikoriza vesicular-arbukular dapat berinteraksi positif dengan bahan organik di dalam tanah sehingga dapat membantu meningkatkan kadar bahan organik hijauan.

Rerata kadar abu hijauan Sorgum pada penelitian ini adalah $11,03 \%$ lebih tinggi dibandingkan penelitian dari Koten (2013) yakni sebesar 10,60\% pada perlakuan tumpangsari legum arbila berinokulum rizobium dengan sorgum .

\section{IV.KESIMPULAN}

Disimpulkan bahwa level penggunaan jamur mikoriza mempengaruhi komposisi nutrisi hijauan sorgum yakni kadar LK, SK dan BETN dan level penggunaan jamur mikoriza terbaik yaitu 5 gram/polibag.

\section{Saran}

Disarankan menggunakan jamur mikoriza 5 gram/polibag untuk menhasilkan hijauan sorgum dengan kualitas nutrisi yang baik dan penelitian mengenai pengaruh level penggunaan jamur mikoriza terhadap komposisi nutrisi hijauan sorgum dapat diterapkan langsung pada lahan dengan jarak tanam yang berbeda.

\section{DAFTAR PUSTAKA}

[1] AOAC. 2005. Official Methods of Analysis of the Association of Official Analytical Chemists. Published by the Association of Official Analytical Chemists. Maryland.
[2] Balabanli, C., S Albayrak and O. Yuksel. 2010. Effects of nitrogen, phosphorus and potassium fertilization on the quality and yield of native rangeland. Turkish Journal of Field Crops, 15(2):164 -168.

[3] Gardner, F. P., R. B. Pearce dan R. L. Mitchell. 2008. Fisiologi Tanaman Budidaya. Terjemahan. UI Press. Jakarta.

[4] Gomez, K.A. dan A.A. Gomez. 2010. Prosedur Statistik untuk Penelitian Pertanian. Terjemahan Edisi Kedua. UI Press. Jakarta.

[5] Koten, B.B., R.D. Soetrisno., N. Ngadiyono dan B. Soewignyo. 2012 ${ }^{\text {a }}$ Perubahan Nilai Nutrien Tanaman Sorgum (Sorghum bicolor (L.) Moench) Varietas Lokal Rote Sebagai Hijauan Pakan Ruminansia Pada Berbagai Umur Panen dan Dosis Pupuk Urea. Pastura Vol. 3 No. $2: 55-60$

[6] Koten, B.B., R.D. Soetrisno., N. Ngadiyono dan B. Soewignyo. 2012 . Produksi Tanaman Sorgum (Sorghum bicolor (L.) Moench) Varietas Lokal Rote Sebagai Hijauan Pakan Ruminansia Pada Berbagai Umur Panen dan Dosis Pupuk Urea Yang Berbeda. Buletin Peternakan Vol. 36 (3): 150-155.

[7] Koten, B.B. 2013. Tumpangsari Legum Arbila (Phaseolus lunatus. L.) Berinokulum Rizobium Dengan Sorgum (Sorghum bicolor (L) moench) Dalam Upaya Produktivitas Hijauan Pakan Ruminansia. Disertasi. Program Pascasarjana Universitas Gadjah Mada. Yogyakarta.

[8] Lukiwati, D.R. 2013. Peningkatan Produksi dan Nilai Nutrisi Hijauan Pakan Dengan Pemupukan Fosfat dan Inokulasi Mikoriza. Lokakarya Nasional potensi dan Peluang pengembangan Usaha Agribisnis Kelinci. hlm. 162-167

[9] Mbeong, Y.S.N. 2016. Pengaruh Level Penggunaan Jamur Mikoriza Terhadap Produksi Hijauan dan Kadar Fosfor Hijauan Sorgum (Sorghum bicolor (L.) Moench). Skripsi. Program Studi Teknologi Pakan Ternak Jurusan Peternakan Politeknik Pertanian Negeri Kupang.

[10] Nugroho, L.H., M.S. Purnomo dan I. Sumardi. 2010. Struktur dan Perkembangan Tumbuhan. Penebar Swadaya. Jakarta.

[11] Nurbaity, A. 2000. Kandungan Logam Berat $\mathrm{Cu}$, Serapan NPK serta Berat Kering Tanaman Padi Gogo (Oryza Sativa L.) pada Tailing PT. Freeport Timika Akibat Aplikasi Mikoriza Vesikular Arbuskular Dan Biostimulan. Thesis program magister. Universitas Padjadjaran. Bandung.

[12] Sirappa, M.P. 2003. Prospek Pengembangan Sorgum di Indonesia Sebagai Komoditas Alternatif untuk Pangan, Pakan, dan Industri. Balai Pengkajian Teknologi Pertanian Sulawesi Selatan. Makassar. Jurnal Litbang Pertanian. 22(4).

[13] Soejono, M. 1991. Petunjuk Laboratorium: Analisis dan Evaluasi Pakan. Pusat Antar Universitas Boiteknologi. Universitas Gadjah Mada. Yogyakarta.

[14] Sutanto, R. 2005. Dasar-Dasar Ilmu Tanah Konsep dan Kenyataan. Penerbit Kanisius. Yogyakarta.

[15] Yoku, O. 2010. Produksi Hijauan dan Nilai Nutrisi Wafer Rumput Sudan (Sorgum Sudaneses) Sebagai Bahan Pakan Ternak Ruminansia. Disertasi. Program Pascasarjana Universitas Gadjah Mada. Yogyakarta. 